\title{
Шляхи удосконалення системи метрологічного забезпечення в сучасних умовах розвитку збройних Сил України
}

\author{
Олег Павловський ${ }^{1}$ А; Олег Сова ${ }^{2}$ в; Володимир Коваль ${ }^{3}$ с \\ А Центральний науково-дослідний інститут Збройних Сил України, м. Київ, Україна

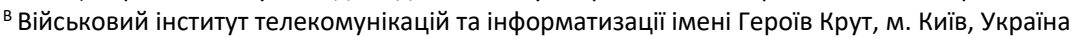 \\ с Генеральний штаб Збройних Сил України, м. Київ, Україна
}

Received: August 15, 2021 | Revised: August 24, 2021 | Accepted: August 31, 2021

DOI: $10.33445 / s d s .2021 .11 .4 .15$

\begin{abstract}
Анотація
Система метрологічного забезпечення Збройних Сил України призначена здійснювати вимірювання та контроль параметрів зразків озброєння і військової техніки. Метрологічне забезпечення в Збройних Силах України організується і здійснюється службами метрології та стандартизації військових частин, оперативних (повітряних) командувань, Генерального штабу Збройних Сил України, а його вдосконалення $\epsilon$ важливою науково-технічною задачею, актуальність якої підтверджується необхідністю підтримання озброєння та військової техніки військ (сил) у боєздатному стані.

В статті проведено аналіз системи метрологічного забезпечення Збройних Сил України та запропоновані шляхи ї̈ удосконалення враховуючи поетапний перехід Збройних Сил України на стандарти НАТО, розвиток озброєння та військової техніки, збільшення обсягів вимірювальних параметрів та стрімкий розвиток інформаційних технологій.

Розвиток високоточного озброєння та військової техніки, систем управління ними, впровадження системи логістичного забезпечення вимагає від нас удосконалення й системи метрологічного забезпечення Збройних Сил України для ії інтеграції в єдину систему управління забезпеченням військ (сил), що дасть змогу оперативно та ефективно вирішувати питання метрологічного обслуговування озброєння та військової техніки, вчасного укомплектування засобами вимірювальної техніки військового призначення, та адекватного контролю за станом метрологічного забезпечення Збройних Сил України.
\end{abstract}

Ключові слова: метрологічне забезпечення, логістичне забезпечення, озброєння та військова техніка, інформаційно-вимірювальна система.

\section{Постановка проблеми}

Як відомо, метрологічне забезпечення направлене на встановлення та застосування наукових й організаційних основ, технічних засобів, правил і норм, необхідних для досягнення єдності та необхідної точності вимірювань. В основі усіх складових метрологічного забезпечення лежать вимірювання, які по суті $\epsilon$ сукупністю операцій, що виконуються для визначення кількісного значення величини. Стан вимірювань, при якому його результати виражені в допущених до застосування в Україні одиницях фізичних величин, а показники точності вимірювань не виходять за встановлені межі, називається єдністю вимірювань. У зв'язку з цим, діяльність метрологічної служби, направлена на досягнення й підтримання єдності

\footnotetext{
${ }^{1}$ Corresponding author: доктор військових наук, професор, начальник науково-дослідного управління (проблем розвитку зС України), е-таі: mafia_sz@ukr.net, ORCID: 0000-0003-2689-3663

2 доктор технічних наук, старший науковий співробітник, начальник кафедри, e-mail: sova_oleg@viti.edu.ua, ORCID: 0000-0002-7200-8955

${ }^{3}$ кандидат військових наук, старший науковий співробітник, заступник начальника Генерального штабу збройних Сил України, е-таі: vladimerkoval69@gmail.com, ORCID: 0000-0002-6209-6779
} 
вимірювань у відповідності із законодавчими актами, правилами та нормами, що встановлені нормативними документами щодо забезпечення єдності вимірювань, що і $€$ основним завданням системи метрологічного забезпечення.

3 розвитком озброєння та військової техніки, засобів його технічного обслуговування і ремонту, впровадженням сучасних інформаційних технологій в Збройних Силах України виникає необхідність удосконалення та адаптації до сучасних умов існуючих систем забезпечення Збройних Сил України до яких відноситься і система метрологічного забезпечення.

\section{Аналіз останніх досліджень та публікацій}

В останніх дослідженнях були запропоновані різноманітні шляхи удосконалення системи метрологічного забезпечення 3С України $[9,10,11]$. Одним 3 пріоритетних напрямків розвитку системи метрологічного забезпечення в зазначених публікаціях розглядається визначення раціональної структури сил і засобів метрологічного забезпечення, раціональний розподіл виїзних метрологічних груп у відповідності до поставлених задач, модернізація пересувних лабораторій вимірювальної техніки (ПЛВТ), а також пропонується інтеграція існуючих зразків ОВТ в систему інтегрованої логістичної підтримки. Разом з тим в зазначених публікаціях не визначається можливість застосування сучасних вимірювальних стандартів в ході проведення метрологічних робіт, використання сучасного парку засобів вимірювання на зразках озброєння та військової техніки та зміна підходів до планування та здійснення метрологічного забезпечення.

\section{Постановка завдання}

На даний час виник певний дисбаланс між зростаючими потребами в метрологічному забезпеченні щодо вимог до точності, повноти, своєчасності, оперативності вимірювань, достовірності контролю параметрів (тактико-технічних характеристик) озброєння та військової техніки та існуючим станом технічної бази, організаційних і нормативних основ метрологічного забезпечення.

Отже, метою статті $\epsilon$ проведення аналізу існуючого стану метрологічного забезпечення ЗС України, визначення недоліків, та вироблення пропозицій щодо шляхів удосконалення системи метрологічного забезпечення ЗС України.

\section{Виклад основного матеріалу}

Метрологічне забезпечення 3бройних Сил України організується та здійснюється відповідно до Закону України № 1314-VII від 15.06.14 "Про метрологію та метрологічну діяльність". Цей Закон визначає правові основи забезпечення єдності вимірювань в Україні, регулює відносини у сфері метрологічної діяльності та спрямований на захист громадян і національної економіки від наслідків недостовірних результатів вимірювань, Постанови Кабінету Міністрів України від 23 грудня 2015 р. № 1152 “Про особливості забезпечення єдності вимірювань у сфері оборони України", яка визначає особливості метрологічного забезпечення діяльності у сфері оборони України, “Положення про метрологічну службу Міністерства оборони України та Збройних Сил України" затвердженого Наказом Міністерства оборони України від 24.05.2017 року № 288. Це Положення визначає завдання, порядок організації i особливості метрологічної діяльності у сфері оборони, а також мету, завдання, порядок організації й здійснення метрологічного забезпечення в Міністерстві оборони України та Збройних Силах України, Державних стандартів України: ДСТУ 2568-94, ДСТУ 2681- 
94, ДСТУ 3231:2007, ДСТУ 3921.1-99, ДСТУ ISO 10012:2005, ДСТУ STANAG 4704:2018 та інших керівних документів.

Метрологічне забезпечення (Мл3) - це комплекс заходів, спрямованих на досягнення єдності вимірювань та достовірності контролю параметрів об'єктів вимірювань військового призначення у 3 С України, інших військових формувань.

У широкому розумінні під МлЗ розуміється комплекс заходів щодо визначення i застосування наукових, нормативних, технічних та організаційних основ, необхідних для досягнення єдності вимірювань, своєчасності та достовірності контролю параметрів об'єктів військового призначення [1-3].

Система Мл3 3С України містить в собі 4 основних складові:

- наукову складову становить метрологія наука про вимірювання та ії̈ військовий напрямок, який враховує специфіку метрологічної діяльності у сфері оборони в умовах як воєнного, так і мирного часу;

- нормативну складову становлять нормативні документи, що визначають зміст і організацію виконання робіт, спрямованих на єдність вимірювань у сфері оборони.

- технічну складову

становить вимірювальна техніка, яка поділяється на засоби вимірювальної техніки військового призначення (ЗВТВП), пересувні лабораторії вимірювальної техніки (ПлВТ) та допоміжне повірочне і калібрувальне обладнання.

- організаційну складову Мл3 військ становить метрологічна служба Міністерства оборони України та ЗС України.

Відповідно, всі ці складові мають відповідати сучасним вимогам, які висуваються до системи Мл3 ЗС України 3 урахуванням сучасних тенденцій та напрямків розвитку ЗС України.

Розвиток наукового підґрунтя з питань Мл3 ЗС України регламентується Законом України “Про наукову і науково-технічну діяльність" від 26.11.2015 року № 848-VIII, наказом Міністерства оборони України "Про затвердження Положення про організацію наукової і науково-технічної діяльності у Збройних Силах України" від 27.07.2016 року № 385 та у відповідності до Плану наукової та науково-технічної діяльності Управління метрології і стандартизації ЗС України. Проте наукову діяльність з питань метрологічного забезпечення необхідно здійснювати за напрямками розвитку 3С України та 3 урахуванням перспектив удосконалення зразків озброєння та військової техніки та засобів їх метрологічного обслуговування.

Проведений аналіз нормативної документації [3-7] з питань Мл3 3С України показав, що на сьогоднішній день положення нормативних документів потребують переопрацювання у відповідності до сучасних вимог, які висуваються до ОВТ, враховуючи місце системи МлЗ в структурі об'єднаного керівництва силами оборони та військового управління у ЗС України [8]. На сьогоднішній день місце системи Мл3 визначається в структурі J4 (логістика), так як на цю структуру покладені завдання 3 планування заходів та визначення потреб у матеріально-технічних засобах та технічного оснащення військ (сил).

Технічна складова системи Млз також потребує оновлення та удосконалення. На сьогоднішній день в 3С України парк ЗВТВП складається з 95 \% приладів, які знаходяться в експлуатації понад 25 років. Проведений аналіз експлуатації ЗВТВП показав, що з цих 95 \% майже половина потребують постійного ремонту, а ще $15 \%$ - взагалі не працездатні. За останні 5-10 років існуючий парк ЗВТВП майже не оновлювався.

Проте, не дивлячись на досить застарілий парк ЗВТВП в ЗС України вже широко впроваджуються автоматизовані вимірювальні системи, які підвищують продуктивність праці військових фахівців у кілька разів. Цим самим досягається суттєве скорочення часу на здійснення контролю параметрів ОВТ та приведення його у бойову готовність. Вже зараз у військах $€$ чимало ЗВТВП 3 мікропроцесорами, здатними 
спільно 3 ПЕОМ забезпечувати автоматизацію процесів вимірювань. Нові радіовимірювальні прилади характеризуються високою надійністю (3-5 тис. годин напрацювання на відмову) і підвищеною точністю вимірювань. Помітно зменшуються габарити і маса приладів [10].

На сьогоднішній день стрімкий розвиток інформаційних, цифрових та бездротових технологій дозволяє створити в складі єдиної автоматизованої системи управління військами інформаційно-вимірювальну систему, що дозволить здійснювати організацію та управління Мл3, віддалений контроль параметрів озброєння та військової техніки, здійснювати прогнозування необхідності здійснення позачергового метрологічного обслуговування озброєння та військової техніки, забезпечити взаємосумісність вітчизняних зразків озброєння та військової техніки з системою інтегрованої логістичної підтримки (ІЛП) або, за західною термінологією - Continuous Acquisition Logistic Support (CALS) [11]. Постачання на озброєння в 3С України новітніх ЗВТВП, які мають канали зв'язку, обладнання зразків ОВТ спеціальними датчиками контролю параметрів, пристроями накопичення, обробки та передачі вимірювальної інформації (блок метрологічного контролю (БМК)), створення в військових метрологічних лабораторіях підрозділів аналізу та обробки цієї вимірювальної інформації, створення єдиної бази даних про стан і наявність ЗВТВП дозволить побудувати вказану вище інформаційно-вимірювальну систему, яка значно підвищить ефективність метрологічного забезпечення ЗС України. Разом з тим застосування новітніх вимірювальних стандартів під час проведення метрологічних робіт на зразках озброєння та військової техніки дозволить здійснювати повірку (калібрування) ЗВТВП, які встановлені на зразках озброєння та військової техніки в режимі on-line. Таку можливість надає новий стандарт вимірювальної техніки LXI.

LXI (LAN eXtensions for Instruments) - новий стандарт вимірювальних систем, який створений та підтримується провідними виробниками контрольно-вимірювального обладнання, що утворили Консорціум LXI, такі як Agilent Technologies, Tektronix, Rohde \&Schwarz, Yokogawa тощо [12, 13, 14, 15].

Застосування вимірювальних приладів та систем з підтримкою стандарту LXI на зразках озброєння та військової техніки дозволить знизити вартість проведення метрологічного обслуговування зразків озброєння та військової техніки, уніфікувати вимірювальне обладнання, забезпечити швидке та ефективне виконання метрологічних робіт на зразках озброєння та військової техніки, що дозволить підвищити їх боєготовність. Разом з тим це дозволить здійснювати віддалений контроль та збір даних про стан параметрів основних агрегатів та систем зразків озброєння та військової техніки, засобів їх контролю та підвищить імовірність своєчасного виявлення відмов в їх роботі.

Аналіз стану ПлВТ показав, що на сьогодні в ЗС України в експлуатації перебуває 58 комплектів ПЛВТ. Основу парку ПЛВТ складають комплекти, що знаходяться в експлуатації понад 25 років та $€$ морально застарілими.

Станом на 01.01.21 за терміном знаходження в експлуатації ПлВТ розподіляється наступним чином: понад 25 років: - 47 од. (60,2\%); від 20 до 25 років - 28 од. (45,1 \%); від 15 до 20 років - 0 од. (0 \%); від 10 до 15 років - 2 од. (2,5\%); до 10 років - 2 од. $(1,4 \%)$.

У відповідності до концепції розвитку системи метрологічного забезпечення 3С України, передбачається створення пересувних повірочно-ремонтних засобів та комплексів. Їх створення повинно базуватися на таких основних принципах:

- забезпечення обслуговування не менш як 85\% парку військових засобів вимірювальної техніки на місцях їх експлуатації;

- радіус дії ПЛВТ повинен бути не менш як 500 км.;

- автономне функціонування у польових 
умовах;

- можливість самоатестації повірочного обладнання ПлВТ за допомогою мір та перетворювачів, що транспортуються;

- побудова на основі агрегатномодульного принципу;

- відповідність номенклатури військових засобів вимірювальної техніки, які обслуговуються у метрологічному напрямку, потребам військ;

- забезпечення гнучкої системної конфігурації, функціональної самостійності, конструктивної, програмної та інших видів сумісності на підставі уніфікованих повірочно-діагностичних модулів.

Слід відзначити, що ці вимоги відповідають світовим тенденціям розвитку парку ПлВТ.

Необхідність створення сучасного парку
ПлВТ для ЗС України обумовлюється вимогами підвищення боєготовності військ за рахунок підвищення ефективності їх Мл3, а також тим, що існуючий парк ПЛВТ морально і фізично застарів.

Державною цільовою оборонною програмою розвитку озброєння та військової техніки на період до 2025 року передбачено створення автоматизованої системи управління логістичним забезпеченням до якої в перспективі можна інтегрувати інформаційно-вимірювальну систему військового призначення для забезпечення циркуляції достовірної вимірювальної інформації про стан параметрів зразків озброєння та військової техніки та засобів вимірювального контролю, що на них встановлені.

\section{Висновки}

Отже, проаналізувавши всі складові системи Мл3 можна зробити висновок, що основними шляхами ї̈ удосконалення $\epsilon$ :

- відповідність наукової та науковотехнічної діяльності з питань Млз напрямкам розвитку ЗС України, вимогам до сучасних зразків озброєння та військової техніки;

- створення та постачання на озброєння в 3С України новітніх ПЛВТ та ЗВТВП 3 підтримкою новітніх вимірювальних стандартів та можливістю інтеграції до перспективної інформаційно-вимірювальної системи;
- модернізація зразків озброєння та військової техніки шляхом обладнання ії спеціальними вимірювальними датчиками, засобами вимірювального контролю 3 підтримкою стандарту LXI для забезпечення можливостей інтеграції озброєння та військової техніки в середовище CALS;

- переопрацювання нормативних документів 3 питань метрологічного забезпечення враховуючи напрямки розвитку ЗС України, зразків озброєння та військової техніки та вимог стандартів НАТО.

\section{Список використаних джерел}

1. Про метрологію та метрологічну діяльність: Закон України (із змінами) (від 05.06.2014 № 1314-VII).

2. Про особливості забезпечення єдності вимірювань у сфері оборони України: Постанова Кабінету Міністрів України від 23.12.2015 № 1152.

3. Положення про метрологічну службу Міністерства оборони України та Збройних Сил України: затв. Наказом Міністерства оборони України від 24.05.2017 р. № 288.
4. Керівництво з організації та порядку експлуатації вимірювальної техніки у Збройних Силах України: затв. Наказом заступника Міністра оборони з озброєння - начальника Озброєння Збройних Сил України від 01.06.2001 № 79.

5. Тимчасова інструкція про уповноваження військових метрологічних лабораторій: затв. Наказом начальника Центрального управління метрології і стандартизації Збройних Сил України Озброєння 
Збройних Сил України - головного метролога Збройних Сил України від 08.10.2018 № 7.

6. Інструкція 3 організації метрологічного обслуговування спеціальної контрольноперевірочної апаратури: затв. Наказом Міністерства оборони України від 19.12.2014 № 907.

7. Перелік військової вимірювальної техніки, що підлягає повірці (атестації) в Збройних Силах України: затв. Наказом Міністра оборони України від 26.11.1994 № 278.

8. Про трансформацію системи об'єднаного керівництва силами оборони та військового управління у зС України: Наказ Міністерства оборони України від 29.03.2019 року № 141.

9. Кузнецов І. Б., Гудима В. П., Хомік М. М. Оцінка ефективності функціонування системи метрологічного забезпечення Збройних Сил України // Збірник наукових праць НУОУ “Труди університету”. - 2016. - №5(138). - С. 148-151.

10. Кузнецов І. Б., Гудима В. П., Дядечко А. О. Аналіз принципів й організаційних основ контролю параметрів зразків озброєння та військової техніки повітряних сил в ході проведення

метрологічного обслуговування // Збірник наукових праць Національного університету оборони України “Труди університету". - Київ: НУОУ ім. І. Черняховського, 2019р. Вип. 1(151), С. 119-128.

11. Воїнов В. В., Бровко М. Б., Запара Д. М. Автоматизований контроль технічного стану зразка ОВТ, як одна з умов інтеграції до середовища CALS // Наука і техніка Повітряних Сил Збройних Сил України. Харків: ХУПС ім. І.Кожедуба, 2015, № 1 (18).

12. Дренкоу Г. Как создать измерительную систему стандарта LXI // Компоненты и технологии. - Санкт-Петербург, 2007, № 2, C. 23-29.

13. Jochen Wolle. State of the LXI Security Working Group // Technical Software Engineering Plazotta. - Wolnzach, Germany, 2019.

14. IEEE1588 and LXI. Data Acquisition and Analysis // National Instruments product catalog, 2015, $231 \mathrm{p}$.

15. LXI-сумісні мікроконтролерні гетерогенні Ethernet-системи дистанційного технічного моніторингу: звіт про НДР (заключ.) // НТУУ “КПІ”, кер.роб. Ю.М.Туз. - Київ, 2013. - 226 с. - Д/б № 2521-п.

\section{Пути усовершенствования системы метрологического обеспечения в современных условиях развития Вооруженных Сил Украины}

\footnotetext{
Олег Павловский * 1 А; Олег Сова 2 в; Владимир Коваль 3 с

Corresponding author: * ${ }^{1}$ доктор военных наук, профессор, начальник научно-исследовательского управления (проблем развития ВС Украины), e-mail: mafia_sz@ukr.net, ORCID: 0000-0003-2689-3663

2 доктор технических наук, старший научный сотрудник, начальник кафедры автоматизированных систем управления, факультета информационных технологий, e-mail: sova_oleg@viti.edu.ua, ORCID: 0000-0002-7200-8955

${ }^{3}$ кандидат военных наук, старший научный сотрудник, заместитель начальника Генерального штаба Вооруженных Сил Украины, е-таі:: vladimerkoval69@gmail.com, ORCID: 0000-0002-6209-6779

А Центральный научно-исследовательский институт Вооруженных Сил Украины, г. Киев, Украина

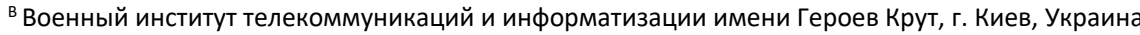
с Генеральный штаб Вооруженных Сил Украины, г. Киев, Украина
}

\section{Аннотация}

Система метрологического обеспечения Вооруженных сил Украины предназначена осуществлять измерения и контроль параметров образцов вооружения и военной техники. Метрологическое обеспечение в Вооруженных силах Украины организуется и осуществляется службами метрологии и стандартизации воинских частей, оперативных (воздушных) командований, Генерального штаба Вооруженных сил Украины, его совершенствование 
является важной научно-технической задачей, актуальность которой подтверждается необходимостью поддержания вооружения и военной техники войск (сил) в боеспособном состоянии.

В статье проведен анализ системы метрологического обеспечения Вооруженных Сил Украины и предложены пути ее усовершенствования, учитывая поэтапный переход Вооруженных Сил Украины на стандарты НАТО, развитие вооружения и военной техники, увеличение объемов измерительных параметров и стремительное развитие информационных технологий.

Развитие высокоточного вооружения и военной техники, систем управления ими, внедрение системы логистического обеспечения требует от нас усовершенствования и системы метрологического обеспечения Вооруженных сил Украины для ее интеграции в единую систему управления обеспечением войск (сил), что позволит оперативно и эффективно решать вопросы метрологического обслуживания вооружения и военной техники, своевременного укомплектования средствами измерительной техники военного назначения, и адекватного контроля над состоянием метрологического обеспечения Вооруженных сил Украины.

Ключевые слова: метрологическое обеспечение, логистическое обеспечение, вооружение и военная техника, информационно-измерительная система.

\title{
Ways to improve the metrological support system in the modern conditions of the Ukraine Armed Forces development
}

\author{
Oleh Pavlovskyi * 1 A; Oleh Sova ${ }^{2}$ B; Volodymyr Koval ${ }^{3 \mathrm{C}}$ \\ Corresponding author: *1 Doctor of Military Sciences, Professor, e-mail: mafia_sz@ukr.net, ORCID: 0000-0003-2689-3663 \\ ${ }_{2}$ Doctor of Technical Sciences, e-mail: sova_oleg@viti.edu.ua, ORCID: 0000-0002-7200-8955 \\ ${ }^{3}$ Candidate of Military Sciences, Head of the Department, e-mail: vladimerkoval69@gmail.com, ORCID: 0000-0002-6209-6779 \\ A Central Scientific and Research Institute of the Armed Forces of Ukraine, Kyiv, Ukraine \\ ${ }^{B}$ Military Institute of Telecommunications and Information Technologies named after Heroes of Kruty, Kyiv, Ukraine \\ ${ }^{c}$ General Staff of the Armed Forces of Ukraine, Kyiv, Ukraine
}

\begin{abstract}
The metrological support system of the Ukraine Armed Forces is designed to measure and control the parameters of weapons and military equipment samples. Metrological support in the Ukraine Armed Forces of is organized and carried out by the metrology and standardization services of military units, operational (air) commands, General Staff of the Ukraine Armed Forces, and its improvement is an important scientific and technical task, the relevance of which is confirmed in combat readiness.

The article analyzes the metrological support system of the Ukraine Armed Forces and suggests ways to improve it, taking into account the gradual transition of the Ukraine Armed Forces to NATO standards, armaments and military equipment development, increasing measurement parameters and rapid development of information technology.

The high-precision armaments and military equipment development, their control systems, the introduction of a logistics system requires us to improve the metrological system of the Ukraine Armed Forces for its integration into a single control system for troops (forces), which will quickly and effectively address metrological weapons and military equipment, timely staffing with measuring equipment for military purposes, and adequate control over the state of the Ukraine Armed Forces metrological support.
\end{abstract}

Keywords: metrological support, logistical support, weapon and military equipment, information and measuring system.

\section{References}

1. On Metrology and Metrological Activity: Law of Ukraine (as amended) (dated 05.06.2014 № 1314-VII).
2. On the peculiarities of ensuring the unity of measurements in the field of defense of Ukraine: Resolution of the Cabinet of 
Ministers of Ukraine dated 23.12.2015 № 1152.

3. Regulations on the metrological service of the Ministry of Defense of Ukraine and the Armed Forces of Ukraine: approved. Order of the Ministry of Defense of Ukraine dated 24.05.2017 № 288 .

4. Guide on the organization and operation of measuring equipment in the Armed Forces of Ukraine: approved. By order of the Deputy Minister of Defense for Armaments - Chief of the Armaments of the Armed Forces of Ukraine dated 01.06.2001 № 79.

5. Temporary instruction on authorization of military metrological laboratories: approved by the Order of the Head of the Central Department of Metrology and Standardization of the Armed Forces of Ukraine Armament of the Armed Forces of Ukraine - Chief Metrologist of the Armed Forces of Ukraine dated 08.10.2018 № 7.

6. Instruction on the organization of metrological maintenance of special control and testing equipment: approved by the Order of the Ministry of Defense of Ukraine dated 19.12.2014 № 907.

7. The list of military measuring equipment subject to verification (certification) in the Armed Forces of Ukraine: approved by the Order of the Minister of Defense of Ukraine dated 26.11.1994 № 278.

8. On the transformation of the system of joint leadership of the defense forces and military management in the Armed Forces of Ukraine: Order of the Ministry of Defense of Ukraine dated March 29, 2019 № 141.

9. Kuznetsov I. B., Gudyma V. P., Khomik M. M.
(2016). Estimation of efficiency of functioning of metrological maintenance system of Ukraine Armed forces. Collection of scientific works of NUOU "Proceedings of university". №5 (138). P. 148-151.

10. Kuznetsov I. B., Gudyma V. P., Diadechko A. O. (2019). Analysis of principles and organizational bases of parameters control of armament and military equipment samples of air forces during carrying out metrological service. Collection of scientific works of the National Defense University of Ukraine "Proceedings of the University". Vol. 1 (151), P. 119-128.

11. Voinov V. V., Brovko M. B., Zapara D. M. (2015). Automated control of the technical condition of the weapons sample, as one of the conditions of integration into the environment CALS. Science and Technology of the Air Force of the Ukraine Armed Forces. № 1 (18).

12. Drenkou G. (2007). How to create a measuring system of the LXI standard. Components and technologies. Sant Petersburg, № 2, p. 23-29.

13. Jochen Wolle. State of the LXI Security Working Group. Technical Software Engineering Plazotta. - Wolnzach, Germany, 2019.

14. IEEE1588 and LXI. Data Acquisition and Analysis. National Instruments product catalog, 2015, $231 \mathrm{p}$.

15. LXI-compatible microcontroller heterogeneous Ethernet-systems of remote technical monitoring: report on research (conclusion). NTUU "KPI", supervisor. Y.M. Tuz. Kyiv, 2013. 226 p. - D / b № 2521-p 